330.341.42

JEL L90, M12

DOI 10.31375/2226-1915-2020-2-26-34

Индах аю Жоханда Путри преподаватель, магистр бухгалтерского учета ORCID https://orcid.org/0000-0001-9853-8113 verrywellgirl@yahoo.com

Сурабаяский торговый морской политехнический институт, Сурабая, Индонезия

\section{ВЛИЯНИЕ ОПЫТА РАБОТЫ \\ И РАБОЧИХ ХАРАКТЕРИСТИК \\ НА РЕЗУЛЬТАТИВНОСТЬ РАБОТЬ СОТРУДНИКОВ СУДОХОДНОЙ КОМПАНИИ}

Аннотация. Цель данного исследования - определить влияние трудового опьта $u$ характеристик работь на эффективность работь сотрудников в судоходных компаниях. В исследовании объясняется связь между индивидуальными и рабочими характеристиками с производительностью труда. Модель и подходы, используемые в этом исследовании, представляет собой исследование с количественным подходом, чтобы объяснить величину влияния между независимыми переменными, а именно переменной опыта работы, и характеристиками работы и зависимой переменной, а именно результатом работы. Сбор данных проводился методом опроса с использованием инструмента анкетирования сотрудников среднего звена су доходной компании, расположенной в Сурабая. Метод анализа данных, используемый в этом исследовании, является множественным линейнымм регрессионным анализом. Результаты этого исследования показывают, что опыт работы влияет на производительность труда, а профессиональные характеристики не оказывают влияния. При этом опыт работы и рабочие характеристики одновременно влияют на производительность труда. дуюшие

Предложения в этом исследовании сле-

1. Компании необходимо уделять внимание фактору опыта работы, чтобы повысить производительность труда.

2. Директор судоходной компании должен разработать стратегию, которая может повысить мотивацию $и$ удовлетворенность сотрудников на работе, что также улучшит производительность труда.

Ключевые слова: производительность труда, трудовой опыт, рабочие характеристики.

\section{(C) Индах аю Жоханда Путри, 2020}

УДК 330.341.42

JEL L90, M12

DOI 10.31375/2226-1915-2020-2-26-34

Індах аю Жоханда Путрі викладач, магістр бухгалтерського обліку ORCID https://orcid.org/0000-0001-9853-8113 verrywellgirl@yahoo.com

Сурабаяський торговельний морський політехнічний інститут. Сурабая, Індонезія

\section{ВПЛИВ ДОСВІДУ РОБОТИ \\ I РОБОЧИХ ХАРАКТЕРИСТИК \\ НА РЕЗУЛЬТАТИВНІСТЬ РОБОТИ \\ ПРАЦІВНИКІВ СУДНОПЛАВНОЇ КОМПАНІЇ}

Анотація. Мета даного дослідження визначити вплив трудового досвіду $i$ робочих характеристик на ефективність роботи співробітників у судноплавних компаніях. $У$ дослідженні пояснюється зв'язок між індивідуальними $i$ робочими характеристиками з продуктивністю прачі. Модель і підходи, які використовуються в иьому дослідженні, $\epsilon$ дослідження 3 кількісним підходом, щоб пояснити величину впливу між незалежними змінними, а саме змінної досвіду роботи, і характеристиками роботи $i$ залежною змінною, а саме результатом роботи. Збір даних проводився методом опитування з використанням інструменту анкетування праиівників середньої ланки судноплавної компанії, розташованої в Сурабая. Метод аналізу даних, який використовується в ијьому дослідженні, $\epsilon$ множинним лінійним регресійним аналізом. $\mathrm{Pe}$ зультати иьього дослідження показують, щзо досвід роботи впливає на продуктивність праці, а робочі характеристики не впливають. При цььому досвід роботи і робочі характеристики одночасно впливають на продуктивність прачі.

Пропозичії в ичьому дослідженні наступні:

1. Компанії необхідно приділяти увагу фактору досвіду роботи, щоб підвищити продуктивність праці.

2. Директор судноплавної компанії повинен розробити стратегію, яка може підвищити мотивацію $i$ задоволеність співробітників на роботі, щуо також покращчить продуктивність npaui.

Ключові слова: продуктивність прачі, трудовий досвід, робочі характеристики. 
UDC 330.341.42

JEL L90, M12

DOI 10.31375/2226-1915-2020-2-26-34

\author{
Indah ayu Johanda Putri \\ Lecturer, Master of Accounting \\ ORCID id https://orcid.org/0000-0001-9853-8113 \\ verrywellgirl@yahoo.com
}

Surabaya Merchant Marine Polytechnic, Surabaya, Indonesia

\title{
THE EFFECT OF WORK EXPERIENCE AND CHARACTERISTICS OF JOBS ON EMPLOYEE WORK ACHIEVEMENT IN THE SHIPPING COMPANY
}

\begin{abstract}
This study aims to determine the effect of work experience and job characteristics on employee work performance in shipping companies. The design or design used in this study is an explanatory research with a quantitative approach, to explain the magnitude of the influence between the independent variables namely the work experience variable and the characteristics of work towards and the dependent variable namely work performance. Data collection was carried out through a survey method using an instrument in the form of a questionnaire towards middle management at a shipping company located in Surabaya. The results of this study are work experience has an influence on work performance, while job characteristics do not have an influence on work performance. Work experience and job characteristics simultaneously influence work performance. The company needs to pay attention to work experience factors as an effort to improve work performance.
\end{abstract}

Keywords: Work Performance, Work Experience, Job Characteristics.

Problem statement. Indonesia is known as a maritime country, because it has sea waters that are larger than the mainland, which has an area of $\pm 3,1$ million $\mathrm{km} 2$. Exports and imports of goods in Indonesia $\pm 70 \%$ are carried out by sea. This is very closely related to the presence of shipping companies in Indonesia. In its development, companies in Indonesia always face several obstacles along with the factors that affect the survival of the company, including human factors. As one of the determining factors, humans have always been the main role both directly and indirectly in the production process and management practices. Furthermore, globalization which affects all aspects of the modern life of humankind demands the company's toughness to compete, both at national and international levels. Companies that want to develop must be able to improve the efficiency and productivity of all their resources and be able to compete with similar companies. One form of competition is how to get a workforce (human resources) that is reliable and agile, so that it can serve and satisfy consumers. Noting these problems the role of human resources becomes important and even urgent in nature to be immediately applied effectively. Likewise for shipping companies, the dissemination of knowledge of human resource management has become a common need, because shipping companies absorb a significant amount of labor. With the development of time, the problems faced by organizations regarding human resource management are increasingly diverse.

Review of the last research and publications. The organization is a gathering place, working together to 
achieve certain goals. The more human resources involved there the more complex the organization. One of the success of an organization depends on individual behavior. To be able to achieve goals effectively and efficiently, an organization must treat individuals humanely by providing work that can meet the needs for food, shelter (providing the means needed), guaranteeing protection, security and avoiding heavy pressure at work, giving the opportunity to interact and involve employees in making decisions, giving awards and opportunities to develop their potential. Because after all, «the level of motivation and commitment of workers to the desires of the organization will be reflected in their satisfaction with work, that is the work that they really have to do. As is well known, high commitment is one of the four things studied in terms of human resource management, in addition to high quality, flexibility and strategic integration (Guest, 1995) In line with this, some organizations that have been amazingly successful in the modern world have recognized that motivation and commitment of workers are the most competitive and powerful (Sadler, 1994: 95). Some studies demonstrate that the level of organizational commitment of an individual says they «do not work as hard as they can do. Employees who work with all their heart show high motivation in carrying out their work. workers who involve themselves, in addition to benefiting the organization, he also will benefit from what it does. With adequate work experience, employees can add the ability to complete the quantity and quality of work. Meanwhile, opening up opportunities to innovate and be creative will encourage workers to deny and show personal potential. In line with this description, industries that have a high level of competition include the shipping industry. The workforce needed for this industry is a specialist workforce, therefore it is not uncommon for middle and upper level workers to move from one company to another. This phenomenon is allegedly related to the commitment of the workforce towards the company. Commitment itself is shaped through individual characteristics and job characteristics. High commitment will improve employee work performance, thus individual characteristics and job characteristics should logically be related to work perfor-mance. Based on this, this study seeks to explain the relationship between individual characteristics and job characte-ristics of work performance.

Research methods. The design of this study is quantitative, because it will test the relationship between dependent and independent variables. Which is an independent variable in this study is work experience and job characteristics, while the dependent variable is work performance. The population in this study were all managers of shipping companies. With a sample of middle managers at a shipping company located in Surabaya. The data analysis technique used in this study is multiple linear regression analysis. With a mathematical model like the following:

$$
\begin{gathered}
\mathrm{Y}=\mathrm{b} 0+\mathrm{b} 1 \mathrm{X} 1+\mathrm{b} 2 \mathrm{X} 2+\mathrm{e} \\
\text { Where } \mathrm{Y}=\text { Job Performance } \\
\mathrm{b} 0=\text { Constant } \\
\mathrm{X} 1=\text { Work Experience } \\
\mathrm{X} 2=\text { Job characteristics } \\
\mathrm{b} 1, \mathrm{~b} 2=\text { Regression Coefficient } \\
\mathrm{e}=\text { error }
\end{gathered}
$$


The basic material of research.

A. Demographics Of Respondents

The data in this study were obtained by distributing questionnaires to the middle managers of shipping companies located in Surabaya. Of the 123 questionnaires sent, 98 were returned.

Gender

Table 1

\begin{tabular}{|c|c|c|}
\hline Gender & Amount & Percentage \\
\hline Female & 37 & $38 \%$ \\
\hline Male & 61 & $62 \%$ \\
\hline
\end{tabular}

Source: Data processed (2019)

Table 2

Age Of Respondent

\begin{tabular}{|c|c|c|}
\hline Information & Amount & Percentage \\
\hline$\leq 25$ & 5 & $5 \%$ \\
\hline $26-30$ & 25 & $26 \%$ \\
\hline $31-35$ & 25 & $26 \%$ \\
\hline $36-40$ & 20 & $20 \%$ \\
\hline$\geq 41$ & 23 & $23 \%$ \\
\hline
\end{tabular}

Source: Data processed (2019)

Table 3

Level Of Education

\begin{tabular}{|c|c|c|}
\hline Information & Amount & Percentage \\
\hline High School & 5 & $5 \%$ \\
\hline Diploma & 15 & $15 \%$ \\
\hline S 1 & 49 & $50 \%$ \\
\hline S 2 & 29 & $30 \%$ \\
\hline S 3 & 0 & $23 \%$ \\
\hline
\end{tabular}

Source: Data processed (2019)

Respondents in this study were $62 \%$ male, and $38 \%$ female. Based on age is $21-30$ years and $31-35$ years, with the same percentage for each is $26 \%$. With the highest level of education is S1, by $50 \%$, then S2, Diploma and High School, with a percentage of $30 \%, 15 \%$ and $5 \%$.

\section{B. Data Analysis}

1. Validity and Reliability Tests

Validity test is measured by looking at the significance value, while reliability is measured by looking at Cronbach's Alpha values. 
Validity and Reliability Test Results

\begin{tabular}{|l|c|c|}
\hline \multicolumn{1}{|c|}{ Variable } & $\begin{array}{c}\text { Alpha } \\
\text { Cronbach Value }\end{array}$ & Significant Value \\
\hline Work Experience & 0,589 & 0,00 \\
\hline Work Charateristics & 0,898 & 0,00 \\
\hline Work Performance & 0,828 & 0,00 \\
\hline
\end{tabular}

Source: Data processed (2019)

From the above table it can be concluded that the instrument used is valid and reliable.

2. Normality Test

Data normality test is done using the KolmogorofSmirnof test. The data in this study are normally distributed because the significance value is greater than 0.05 . The following table tests data normality:

Data Normality Test

Table 5

One-Sample Kolmogorov-Smirnov Test

\begin{tabular}{|l|l|c|c|}
\hline \multicolumn{2}{|l|}{} & $\begin{array}{c}\text { Unstandardtz } \\
\text { ed Residual }\end{array}$ \\
\hline N & & & 98 \\
\hline Normal Parameters & Mean & & .0000000 \\
\hline & Std. Deviation & & 2.29574809 \\
\hline Most Extreme Differences & Absolute & & .079 \\
\hline & Positive & & .079 \\
\hline & Negative & .041 \\
\hline Kolmogorov-Smirnov Z & & .786 \\
\hline Asymp. Sig. (2-tailed) & & & .567 \\
\hline
\end{tabular}

a. Test distribution is Normal

Source: Data processed (2019) 
MulticollinearityTest

\begin{tabular}{|c|c|c|}
\hline Variable & VIF Value & Tolerance Value \\
\hline X1 (Work Experiances) & 1,675 & 0,619 \\
\hline X2 (Work Characteristics) & 1,675 & 0,619 \\
\hline
\end{tabular}

Source: Data processed (2019)

3. Classical Assumption Test

Classification assumption tests include multicollinearity, autokoleration and heteroskedacity. Multicollinearity tests are carried out by looking at tolerance and VIF values. Multicollinity does not occur if the tolerance value $>$ 0.100 and VIF $<10$. For heteroskedacity test using scaterploot, if the points are random random and do not form patterns, then heteroscedacity does not occur. For autokoleration using Durbin Watson, there is no autokoleration if the durbinwatson value is between du and 4-du. Here are the results from the classic assumption test:

\section{Normal P.P Plot of Regression standardized Fesidual}

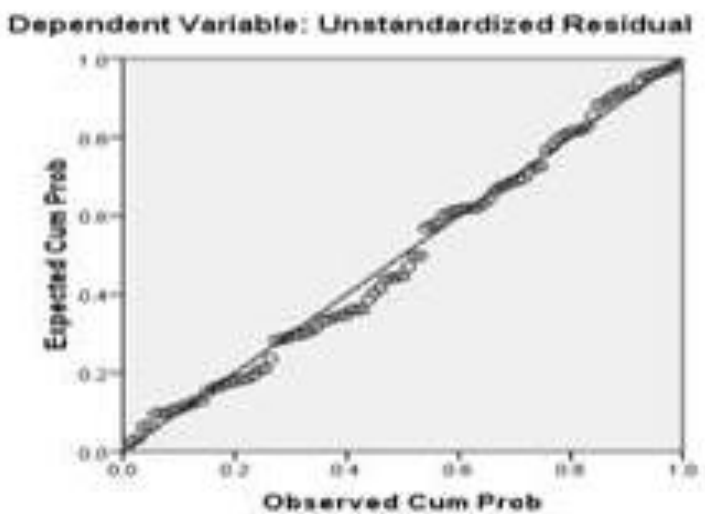

Fig. 1.Test Heteroscedacity

Source: Data processed (2019)

Autokoleration Test

\begin{tabular}{|l|l|l|}
\hline $\mathrm{Du}$ & Durbin Watson & $4-\mathrm{Du}$ \\
\hline 1,713 & 1,958 & 2,287 \\
\hline
\end{tabular}

Source: Data processed (2019) 
Based on the above table, it is known that the data in this study are free from multicollinearity, heteroskedacityand autokoleration.

4. Model Significance Test (Test F)

The F test was carried out to determine the simultaneous effect of work experience and job characteristics on work performance. Based on the results of the $\mathrm{F}$ test, it is known that the significance value is 0,000 . So it can be concluded that work experience and job characteristics simultaneously influence work performance. With the magnitude of influence of $26 \%$, it means that the factors affecting work performance by $26 \%$ are influenced by work experience and job characteristics, while $74 \%$ are influenced by factors outside of work experience and job characteristics.

5. Hypothesis Test ( $\mathrm{t}$ Test)

After testing the normality and classic assumptions. Then the linear regression test is performed. This test is conducted to determine whether there is influence and the magnitude of the influence of independent variables on the dependent variable.

Table 8

Test $t$

\begin{tabular}{|l|c|c|c|c|}
\hline \multirow{2}{*}{ Information } & \multicolumn{2}{|c|}{ Unstandardized Coefficient } & \multirow{2}{*}{$\mathrm{t}$} & \multirow{2}{*}{ Sig } \\
\cline { 2 - 3 } & $\mathrm{B}$ & Std. Error & & \\
\hline Constant & 9,165 & 0,943 & 9,715 & 0,000 \\
\hline X1 (Work Experience) & 0,815 & 0,190 & 4,295 & 0,000 \\
\hline X2 (Work Characteristics) & 0,049 & 0,099 & 0,493 & 0,623 \\
\hline
\end{tabular}

Source: Data processed (2019)

Based on table 4.2.5.1 above, the linear regression equation can be written as follows: $\mathrm{Y}=9,165+0,815 \mathrm{X} 1+$ $0,049 \mathrm{X} 2+\mathrm{e}$

The above equation can be explained as follows:

1. If the value of work experience and job characteristics are considered constant, then the value of work achievement is 9,165 . That is, work performance is still achieved even without work experience and job characteristics.

2 . The coefficient value of experience on work performance is positive and is 0,815 . This means that each increase in work experience by one unit, then the variable work performance will increase by 0,815 .
3. The coefficient value of job characteristics on work performance is positive and has a value of 0,049 . This means that each increase in job characteristics by one unit, then the variable work performance will increase by 0,049 .

To test the hypothesis, it is done by seeing the value of significance $t$. Based on table 8, which has a significance value below 0.05 is a work experience variable. Thus, the work experience variable has an influence on work performance. While job characte-ristics do not have an influence on work performance.

Based on the F test results are obtained that work experience and job 
characteristics simultaneously influence work performance. This is evidenced from the significance value in the $\mathrm{F}$ test that is smaller than 0,05 . And from the results of hypothesis testing ( $t$ test), it is known that the significant effect on work performance is work experience, because the significance value of work experience is less than 0.05 . The coefficient value of work experience of 0,815 means that each increase in work experience is one unit, so the work performance variable will increase by 0.815 . The results of this study are in line with the opinion of Siagian (Siagian, 2015): «Work experience shows how long it takes for employees to work well». In addition, work experience includes the many types of jobs or positions that have been occupied by someone and their duration of work in each of these jobs or positions (Swasto, 1996). Thus, years of service is one of the individual factors related to individual behavior and perception. For examp-le, the reason someone who has worked fifteen years or more in looking at a situation is completely different from a worker who has worked for a year. Work experience that has been obtained by an employee will be able to improve his ability to carry out work. Workers who have high ability make it possible to get higher rewards, both intrinsic and extrinsic, so that it will strengthen and increase its commitment to the organization, as stated by Steers (Steers, 1985) to increase employee commitment can be done by offering rewards that apply throughout the organization to the its members such as relatively high salary levels, good additional facilities, opportunities for personal growth and progress.

Job characteristics do not have an influence on work performance because of the results of the $t$ test, the significance value is 0,623 , which means it is greater than 0,005 . The results of this study support the research of Bashaw (Edward Bashaw \& Stephen Grant, 2014) and. Job characteristics are related to variations in skills, job identity, task significance, autonomy and feedback. feedback. The series of dimensions of the work if linked to psychological conditions will be able to provide work motivation and high job satisfaction so that work performance can be achieved. However, in this study the characteristics of work do not have an influence on work performance. This means that managers in shipping companies lack motivation and high job satisfaction. So that for them work is considered as something that is less meaningful or important, lacks a sense of responsibility for the results of the work personally and has not been able to ascertain in an orderly and reliable manner how the business results, what results have been achieved, and whether the results were satisfactory or no (Edgar, 1991)

Conclusions and suggestions. Based on the results of hypothesis testing, then:

1. Work experience has a positive effect on work performance.

2. Job characteristics do not affect work performance.

3. Work experience and job characteristics simultaneously influence work performance. as follows:

The suggestions in this study are

1. The company needs to pay attention to work experience factors as an effort to improve work performance. Because work experience is a factor that influences work performance improvement. 
2. The director of the shipping company should make a strategy that can increase employee motivation and employee satisfaction at work. Because employee motivation and job satisfaction can improve work performance.

\section{REFERENCES}

1. Edgar, H.S. (1991). Organizational Culture and Leadership. San Frasisco: Oxford Jossey Bass Publisher.

2. Edward Bashaw, R., \& Stephen Grant, E. (2014). Exploring the distinctive nature of work commitments: Their relationships with personal characteristics, job performance, and propensity to leave. Journal of Personal Selling and Sales Management, XIV(2).

3. Guest, D.E. (1995). Human resource management, trade unions and industrial relations. Human Resource Management: A Critical Text, 1, 110-142.

4. Siagian, S.P. (2015). Manajemen Sumber Daya Manusia. Jakarta: Bumi Aksara.

5. Steers, M.R. (1985). Organizational Effectiveness: A Behavior View. Jakarta: Erlangga.

6. Swasto, B. (1996). Pengembangan Manajemen Sumber daya Manusia pengaruhnya terhadap kinerja dan Imbalan. FIA UB Malang.

Article received 23.03.2020

Reference a JournalArtic: Indah ayu Johanda Putri. (2020). The effect of work experience and characteristics of jobs on employee work achievement in the shipping company. Development of management and entrepreneurship methods on transport. 2, 26-34. DOI 10.31375/2226-19152020-2-26-34. 